\title{
SURVEY OF FEDERAL LEGISLATION AFFECTING PRIVATE HOME FINANCING SINCE 1932
}

\author{
E. S. WALLACE*
}

Reliable estimates indicate that between I92I and I93I the amount of the indebtedness on urban real estate in the United States more than trebled; this debt per capita more than doubled; the ratio of this debt of real estate values more than trebled; and the ratio of the annual charges on this debt to the national income more than doubled. ${ }^{1}$ The burden of the debt was, of course, increased by the decline in income and property values during the depression. By 1932 the number of foreclosures in urban areas, which had risen steadily even during the years of prosperity, had mounted to nearly four times the 1926 level. ${ }^{2}$ New lending had practically ceased. Such demand for loans as existed arose almost entirely from the necessity of refinancing existing obligations, and lending institutions, pressed for liquidity, were unable to meet even this demand. These developments focused attention on certain basic defects which had long existed in this portion of the credit system. The most important of these defects may be listed as follows: ${ }^{3}$ (I) the instability of real estate values, resulting from population movements and enhanced by the flow of speculative funds into and out of the real estate market, which has caused lenders to restrict their first mortgage loans to rather low percentages of appraised property values; (2) the unsatisfactory, costly, and frequently illegal system of second and third mortgages, resulting from the fact that many families attempting home ownership have not been able to provide from their own funds the difference between the amount of

- A.B., 1930, Birmingham-Southern College; A.M., 1931, Ph.D., 1937, Duke University. Assistant Professor of Economics, Hendrix College. Author of "The Federal Home Loan Bank System," an unpublished doctoral dissertation.

${ }^{2}$ Crark, The Internal Debts of the United States (1933) c. III. This study did not attempt a segregation of residential and other urban mortgage debts, but the former constitute about two-thirds of the total, hence the figures probably give a rough approximation of the facts with regard to home indebtedness.

Because of the assumption that the proportion of the total debt held by lending groups other than banks, life insurance companies, and building and loan associations was considerably larger in I92I than in the 1930's, the estimates of Horton (Long Term DebTs in the United States, U. S. Dep't of CoMMERCE, DOM. COMM. SERIEs, No. 96 (1937)) indicate a somewhat smaller increase in total indebtedness than those of Clark.

2An index of foreclosures, extending back to 1926 , has been published monthly in the Federal Home Loan Bank Review since April, 1936. For details on method of construction, see (1936) 2 F. H. L. B. REv. 229-231. Comparable figures prior to 1926 are not available.

"For an excellent discussion of these points, except the last, by John H. Fahey, Chairman of the Board, see The Government's Program for the Organization of the Nation's Home Financing System (1934) 1 F. H. L. B. REV. I-I 4. 
the first mortgage, thus restricted, and the cost of the home; (3) inefficient methods of appraisal, which have made property values an extremely vague and tenuous basis on which to judge the safety of a loan and have frequently made it possible for a prospective borrower to "shop around" from one institution to another and give his business to the one appraising his property at the highest figure; (4) the use of shortterm funds of financial institutions having demand obligations for loans on real estate mortgages, which by their very nature are a long-term investment; ${ }^{4}(5)$ the use of short-term, unamortized loans-a policy, encouraged by federal and state legislation, which obviously has not succeeded in securing the necessary liquidity but which has been in part responsible for the undesirable form in which most home mortgage credit has been extended; ${ }^{5}(6)$ the isolation of lending agencies from the capital markets of the country and the absence of any mechanism for their interregional transfer of funds, which have made most lending agencies entirely dependent on the local resources of their own communities and have resulted in a very uneven flow of credit for home financing; (7) the attempt, fostered largely by financially interested groups on sentimental or emotional grounds, to extend home ownership to classes unable to afford it on the available terms and to sell others more expensive properties than they could afford, which has resulted in the assumption by many of debt charges far beyond their capacity to bear and thus swelled the volume of foreclosures, increased the fluctuations in real estate values, and destroyed the home ownership aspirations of others with adequate financial resources to undertake it.

It was in an effort to remedy some of these defects inherent in the home financing machinery, cope with the almost complete breakdown of this machinery that took place during the depression, and alleviate unemployment by stimulating new construction that the extensive program of rehabilitation embodied in the legislation here surveyed was undertaken by the federal government. This program will be discussed under the following headings: (I) the Federal Home Loan Bank System, (2) refinancing by the Home Owners' Loan Corporation, (3) share investment by this corporation and the Federal Treasury in local home financing institutions, (4) federal savings and loan associations, (5) the Federal Savings and Loan Insurance Corporation, (6) the Federal Housing Administration, and (7) devices to provide a national mortgage market. The pertinent statutes, with their citations, are listed in chronological order in Table I. These statutes are referred to by their dates and without further citation in the discussion which follows. Other legislation relating to the financing of homes is beyond the scope of this survey. ${ }^{\circ}$

\footnotetext{
'It is estimated that in October, 1933, there were approximately $\$ 500,000,000$ of frozen real cstate mortgages in closed and restricted banks, and in many cases, of course, the presence of such mortgages was a primary reason for the necessity of closing.

${ }^{8}$ It is estimated that approximately two-thirds of the urban home mortgage indebtedness in $x 929$ was represented by mortgages made for original terms of from one to five years, with no amortization provisions, which therefore came due during the depression, when liquidation, renewal, or refinancing was usually impossible.

- The discussion is confined to legislation concerned with the private financing of urban homes. Therefore, the various laws dealing with agricultural eredit and the Wagner-Steagall Act of Sept. I, 1937,
} 
TABLE I

Chronological List of Statutes Discussed

\begin{tabular}{|c|c|c|c|c|c|}
\hline $\begin{array}{l}\text { Date of } \\
\text { Approval }\end{array}$ & Title or Content & $\begin{array}{c}\text { Public } \\
\text { No. }\end{array}$ & Cong. & Sess. & Reference \\
\hline July 22,1932 & Federal Home Loan Bank Act & 304 & 72 & 1 & $\begin{array}{l}47 \text { Srar. 725-741, } \\
12 \text { U.S.C., c. } 11\end{array}$ \\
\hline July 22,1932 & $\begin{array}{l}\text { Appropriation for Federal Home } \\
\text { Loan Bank Board }\end{array}$ & 305 & 72 & 1 & 47 Stat. 741 \\
\hline June 13,1933 & Home Owners' Loan Act & 43 & 73 & 1 & $\begin{array}{l}48 \text { STAT. } 128-135 \\
12 \text { U.S.C., c. } 12\end{array}$ \\
\hline June 16,1933 & Fourth Deficiency Act, 1933 & 77 & 73 & 1 & 48 Stat. 274, 279 \\
\hline April 27,1934 & Guaranteeing Bonds of HOLC & 178 & 73 & 2 & 48 Stat. $643-647$ \\
\hline June 27,1934 & National Housing Act & 479 & 73 & 2 & $\begin{array}{l}48 \text { STAT. } 1246-1265 \text {, } \\
12 \text { U.S.C., c. } 13\end{array}$ \\
\hline Jan. 31,1935 & Extending Functions of RFC & 1 & 74 & 1 & 49 STॄAT. 1,3 \\
\hline May 28,1935 & $\begin{array}{l}\text { Act to Provide Additional Mort- } \\
\text { gage Relief }\end{array}$ & 76 & 74 & 1 & 49 Stat. $293-300$ \\
\hline Aug. 23, 1935 & $\begin{array}{l}\text { Banking Act of } 1935 \text { (including } \\
\text { amendments to National Hous- } \\
\text { ing Act) }\end{array}$ & 305 & 74 & 1 & 49 StAт. $684-723$ \\
\hline April 3,1936 & $\begin{array}{l}\text { Extension of } \$ 2 \text { of National Hous- } \\
\text { ing Act }\end{array}$ & 486 & 74 & 2 & 49 Stat. $1187-1188$ \\
\hline April 17, 1936 & $\begin{array}{l}\text { Insurance of Catastrophe Loans } \\
\text { by FHA }\end{array}$ & 525 & 74 & 2 & 49 Stat. 1232-1234 \\
\hline June 22,1936 & First Deficiency Act, 1936 & 739 & 74 & 2 & 49 Stat. 1597, 1647 \\
\hline Feb. 19,1937 & $\begin{array}{l}\text { Extension of } \$ 204(b) \text { of National } \\
\text { Housing Act }\end{array}$ & $\begin{array}{l}\text { Pub. } \\
\text { Res. } 6\end{array}$ & 75 & 1 & 50 Star. 20 \\
\hline April 22, 1937 & $\begin{array}{l}\text { Amendments to National Housing } \\
\text { Act (insurance of Catastrophe } \\
\text { Loans by FHA) }\end{array}$ & 44 & 75 & 1 & 50 SтAт. $70-71$ \\
\hline Feb. $\quad 3,1938$ & $\begin{array}{l}\text { Amendments to National Housing } \\
\text { Act }\end{array}$ & 424 & 75 & 2 & 52 Stat. 8 \\
\hline
\end{tabular}

\section{The Federal Home Loan Bank System}

Taking somewhat of a middle ground between the details of various plans submitted for dealing with the home mortgage problem in the early stages of the depression, President Hoover proposed creation of a system of Federal Home Loan Banks in a press announcement on November $\mathrm{I}_{3}, \mathrm{I}$ 193 ${ }^{\top},{ }^{\top}$ and formally recommended it to Congress in his messages of December 8, I931, and January 4, 1932. ${ }^{8}$ From these

50 STAT. 888,42 U. S. C. (I937 Supp.) c. 8, creating the United States Housing Authority to provide federally-financed slum clearance and low-cost housing projects, are excluded. The agency just mentioned should not be confused with the Federal Housing Administration, which is described below.

'The President's statement is given in full in the New York Times, Nov. I4, I93 I, p. 2, and in 2 Publications of the Prestdent's Conference on Home Building and Home Ownership (1932) 98-ior.

${ }^{8} 75$ Conc. Rec. 24-25, 1263 (1932). 
statements of the President, it is apparent that the system was originally intended to contribute toward relief of financial institutions and home owner borrowers, toward recovery, through revival of residential construction and the consequent stimulus to industries dependent thereon, and toward reform of the mortgage lending system "to safeguard against the repetition of such experiences in the future." After a lengthy Congressional struggle, final action on the proposal came just before adjournment, July $16,193^{2}$, and the bill became law with the President's signature on July $22 .{ }^{9}$

Provisions of the Law. ${ }^{10}$ Like the Federal Reserve System in its original form, the Federal Home Loan Bank System consists of four parts:

I. The Federal Home Loan Bank Board. ${ }^{11}$ At the head of the system is the Board, consisting of five members, not more than three of whom may be of the same political party, appointed by the President with the advice and consent of the Senate for six-year overlapping terms. The Board is given very wide powers, comparable in many respects to those of the Board of Governors of the Federal Reserve System. ${ }^{12}$

2. The Federal Home Loan Banks. ${ }^{13}$ The Board was charged with the duty of dividing the country into not less than eight nor more than twelve districts ${ }^{14}$ and of designating a city in each at which the bank for that district should be located. The minimum capitalization of each bank was fixed at $\$ 5,000,000$. Stock in the bank may be purchased by institutions eligible for membership at the rate of one per cent of the unpaid principal of home mortgages held by them. ${ }^{15}$ The law directed that after subscription books had remained open for thirty days the balance necessary, up to $\$ 125,000,000$, to make up the minimum capitalization prescribed by the Board should be subscribed by the Secretary of the Treasury on behalf of the government and paid

\footnotetext{
- The length of time required to secure enactment of the law is indicative of the lack of enthusiasm for it on the part of Congress as a whole. It seems fair to conclude that the bill was passed, not on its own merits, but because it was an administration measure, and because many of the Democrats, who had come into control of the House, were unwilling, with the country in the throes of depression and a Presidential election approaching, to appear to be standing in the way of any part of the President's program of economic relief. The persistent lobbying of representatives of the United States Building and Loan League, although entircly unauthorized by any formal action of its membership, was an important factor in keeping the proposal before Congress and securing final enactment of the law.

${ }_{10}$ The original Act has been amended four times (by the Acts of June 13, 1933, April 27, 1934, June 27, 1934, and May 28, 1935). Instead of discussing the provisions of cach of these separately, it has seemed preferable to summarize the law in its present form, mentioning in footnotes the respects in which it differs from the statute under which the system commenced operations.

"Referred to throughout as "the Board."

${ }^{22}$ One of the members of the original Board said in 1932 that it had more power than the Federal Reserve Board and the Federal Farm Board combined, and that the provisions of the law giving it power to make rules and regulations were "among the broadest features ever written into a piece of legislation." Building and LOAN ANnals, 1932, pp. 15, I6. (Hercafter cited as "Annars.") This tendency to grant administrative authorities broad powers to make rules and regulations has been continued and extended in later legislation. It is especially noticeable in the law governing operations of the FHA.

${ }^{13}$ Referred to hereafter as "the banks." 10 "Twelve districts were actually established.

${ }^{15}$ Under the Board's interpretation of the law, members may purchase additional amounts of stock whenever they desire. In order to make membership less burdensome for the smaller institutions, the minimum subscription required was changed from $\$ 1500$ to $\$ 500$ by the Act of June 27,1934 .
} 
at the call of the Board with funds obtained from the RFC. ${ }^{16}$ All stock shares equally in dividend distribution. ${ }^{17}$ Each district bank is administered by a board of directors of twelve members, four appointed by the Board and eight elected by member institutions. ${ }^{18}$ The banks pay their own expenses, and are required to pay, beginning July $x$, $1933,{ }^{18}$ semi-annual assessments levied in advance by the Board to cover its expenses, and immediate assessments whenever necessary to cover defi-a ciencies between semi-annual assessments.

3. Member institutions. As in the Federal Reserve System, membership is both compulsory and voluntary. Federal savings and loan associations, the "national banks" of the urban mortgage lending field, must be members of the system, while state-chartered building and loan associations, insurance companies, and savings banks are permitted to join. ${ }^{20}$ Institutions for which membership is voluntary may withdraw after six months' notice. In order to be eligible for membership, institutions must (a) be duly organized under the laws of a state or of the United States; (b) be subject to inspection and regulation under such laws or, if not, must subject themselves to such inspection and regulation as the Board prescribes; (c) make what the Board considers long-term loans; (d) secure the approval of the Board with regard to their financial condition and the character of their management; (e) not charge usurious rates of interest. ${ }^{21}$

4. The Federal Savings and Loan Advisory Council.22 This council is composed of one member elected annually by the board of directors of each bank and six members appointed annually by the Board, all of whom serve without compensation. It

\footnotetext{
18 Government stock may be retired at any time in the discretion of the Board. After the amount of capital of a bank paid in by members equals the amount paid in by the government, one-half of all sums thereafter paid in by members is to be applied to retirement of stock held by the government.

${ }^{17}$ The provision of the original Act for $22 \%$ cumulative preference on government stock was repealed by the Act of May 28, 1935. See 79 Conc. Rec. 314I (1935); (1935) I F. H. L. B. REv. 280.

${ }^{10}$ The number of directors was increased from eleven, and the qualifications and method of election were changed by $\$ 3$ of the Act of May 28, I935. For the previous provisions, see $\$ 7$ of the original Act.

20 For expenses of the Board prior to that date, \$250,000 w2s appropriated by an Act approved July 22, 1932.

The wording of the law also includes savings and loan associations, cooperative banks, and homestead associations, but these are merely other names by which building and loan associations are known in certain states. Provision is also made for membership, under certain conditions, by state-chartered and supervised reserve associations whose membership is confined exclusively either to building and loan associations or to savings banks. Such associations exist in New York and Massachusetts, but they have not joined the bank system.

The requirement that federal associations become members was included in the Act of June 13,1933 , which authorized their creation.

at The La Guardia amendment ( $\$ 5$ of the original Act), adopted in spite of administration and build ing and loan opposition, prohibits an institution from becoming a member or non-member borrower if the combined total of amounts paid it for interest, commission, bonus, discount, premium, and other similar charges, less a proper deduction for all dividends, refunds, and cash credits, creates an actual net cost to the borrower in excess of the maximum legal rate of interest or lawful contract rate, regardless of any exemption from usury laws, in the state where the property is located, or in case there is no rate established by law, in excess of $8 \%$.

" Provision for this council was made by the Act of May 28, 1935, at the request of members of the system, who felt that the Board should receive advice from an agency not composed entirely of its own appointees. There had previously been two advisory councils, created by the Board on its own initiative, one consisting of the chairmen of the boards of the banks, the other of the bank presidents. The latter still functions.
} 
has power to confer with the Board, request information, and make recommendations concerning matters within the jurisdiction of the Board, and must meet in Washington at least twice a year and oftener if requested by the Board.

With one exception, ${ }^{23}$ advances by the banks may be made only to member institutions. ${ }^{24}$ They are made on the note of the borrowing institution and bear a rate of interest approved or determined by the Board. ${ }^{25}$ Thus the banks are lending, not rediscount, institutions. Advances with maturity of not more than one year may be made without any security to institutions whose creditor liabilities (not including advances from the banks) do not exceed $5 \%$ of their net assets. ${ }^{28}$ With this exception, notes of borrowers must be secured by a lien on the Home Loan Bank stock owned by them, and by collateral consisting of eligible home mortgages or obligations of or fully guaranteed by the United States. ${ }^{27}$ Aggregate outstanding advances to a member may not exceed twelve times the amount paid in by it on the capital stock of the bank. ${ }^{28}$

The banks may accept deposits of members, other banks, other instrumentalities of the United States, and public funds, except customs receipts. ${ }^{29}$ In addition to these

${ }^{23}$ The banks are authorized by the Act of May 28, I935, under certain conditions, to make advances to non-member mortgagees approved for mortgage insurance by the FHA under Title II of the National Housing Act. This Act had made provision for national mortgage associations to provide a national market for insured mortgages (see infra, p. 506), but none of these associations had been organized, and this provision was inserted in the Home Loan Bank Act in an attempt to give the desired liquidity to such mortgages.

24 The Couzens amendment ( $\$ 4$ (d) of the original Act) permitted the banks, so long as the government should hold stock in them, to lend directly to individuals who were unable to obtain loans from any other source. This section of the law was easily nullified in practice by the interpretations and policies of the banks and of the Board. See 76 CoNe. Rec. 1328-29, 2533 (1933). It was repealed in less than a year by the Act of June 13,1933 , in which Congress dealt directly with the problem of individual urban mortgage diffculties, but it provided the basis for a great deal of misrepresentation, misunderstanding, and confusion in setting up the system.

The original Act also authorized loans to cligible institutions in states whose laws did not permit them to become members. This provision expired by its own limitation with the passage of enabling legislation or the expiration of the next regular session of the legislature in each of these states.

$\approx$ Under the original Act the rate of interest was indirectly limited to $7 \%$ for the first seven years and $6 \frac{1}{2} \%$ thereafter. See note $3 \mathrm{I}$, infra.

${ }^{20}$ Under present regulations of the Board, the banks are authorized to make advances on an unsecured basis or on any kind of security readily available to members even though they cannot meet this requirement. Such advances, which require special types of approval, may not be made for more than thirty days and must either be paid or refunded on a secured basis at the end of that time. They are designed merely to take care of exeeptional emergency conditions and are authorized under the broad terms of $\oint_{\text {I I }}(\mathrm{g})$ (3) of the Act, which permits "advances with a maturity of not to exceed one year ... . to members ... upon such terms and conditions as the Board may prescribe."

${ }^{27}$ Government obligations were made eligible by the Act of May 28, 1935, with bonds of the HOLC particularly in mind. The types of mortgages eligible as collateral and the maximum percentages that might be lent on each were specified in detail in $\$ 10$ (a) and (b) of the original Act. In an attempt to make membership more attractive, the requirements were relaxed and the percentages increased by 510 of the Act of April 27, 1934, \$\$501, 502, and 507 of the Act-of June 27, 1934, and $\$ \$ 1,5$, and 6 of the Act of May 28, x935. In general, an eligible mortgage must be a first lien, not exceeding $\$ 20,000$ and not more than six months past due, on real estate containing a dwelling for not more than four families. It should be noted that the law does not confine eligibility to mortgages on urban real estate.

${ }^{23}$ Under present regulations of the Board, a member's borrowing capacity is the amount for which it may legally obligate itself or $50 \%$ of its net assets (share capital), whichever is lower.

2 The original law excluded other instrumentalities of the United States and provided that deposits should not be subject to check and should not receive interest of more than $2 \%$. The change was made by the Act of June 27, 1934 . 
deposits and its capital, the system may secure further funds by borrowing, which may take three forms: (I) Consolidated Federal Home Loan Bank debentures may be issued by the Board as the joint and several obligations of all the banks, providing there is no existing lien on any of the assets of any of the banks and that no such lien is incurred while the debentures are outstanding. These debentures may not exceed five times the total paid-in capital of all the banks, nor may they exceed the total of all obligations of borrowing members held by the banks. (2) Consolidated Federal Home Loan Bank bonds, with security, terms, and conditions prescribed by the Board, may be issued as the joint and several obligations of all the banks whenever no debentures are outstanding or for the purpose of refunding all outstanding consolidated debentures. ${ }^{30}$ (3) Debentures, bonds, or other obligations may be issued by the individual banks, subject to rules and regulations prescribed by the Board. ${ }^{31}$ All three types of obligations are made acceptable at par in settlement of indebtedness to the banks and eligible as lawful investments and security for all fiduciary, trust, and public funds under the control of the United States, and are exempt both as to principal and interest from all local, state, and national taxation except surtaxes, estate, inheritance, and gift taxes. ${ }^{32}$ The law specifically states, however, and requires that the obligations shall state that they are not obligations of, or guaranteed by, the United States.

Extent of Operations. ${ }^{33}$ The system was faced with many obstacles in beginning its operations, ${ }^{34}$ and although the banks were technically opened on October 15, 1932,

${ }^{20}$ The Act is not clear as to whether these bonds could be issued while the individual banks had obligations outstanding, but apparently they could, providing such obligations of the individual banks were not called debentures. So far as the law is concerned, the only difference between the debentures and the bonds is that there is no limitation on the amount of the latter that may be issued. It may be assumed, however, that the bonds would be secured by specific collateral, which would automatically limit their amount.

a The original Act made provision for borrowing only by the individual banks. Their bonds and debentures, which were to be joint and several obligations of all the banks, were to be issued on a basis that would guarantec at least \$19o of unpaid mortgage principal (or temporarily, when mortgages were not available, $\$ 100$ in cash or government obligations) back of every $\$ 100$ worth of outstanding obligations. The rate of interest on such securities issued within seven years after enactment of the law was not to exceed $5 \frac{1}{2} \%$, and thereafter was not to exceed $5 \%$. The margin between interest paid by the bank and that received upon advances was not to exceed $1 \frac{1}{1} \%$. The section of the law dealing with borrowing was completely rewritten in its present form by the Act of June 27,1934 . This revision has removed all Jimitation on the amount of borrowing by the system, the rate of interest that may be paid, and the rate of interest that may be charged by the banks on their advances.

Under the revision of its "Regulation A," which defines paper eligible for discounts and advances at the Federal Reserve banks, issued by the Board of Governors in September, I937, they are also made cligible as collateral for advances under $\$ 10(b)$ of the Federal Reserve Act as amended by the Banking Act of 1935 . See p. 508, infra. Thus far the attempts to make these obligations eligible for direct purchase and open market operations by the Federal Reserve Banks and to give the Home Loan Banks access to Federal Reserve loans have not succeeded.

${ }^{3}$ Some operating statistics for the bank system and the other agencies under the Board's jurisdiction are published monthly in the Federal Home Loan Bank Review, and the February issue each year contains a fairly complete review of the previous year's operations. Figures used throughout this article have been obtained from this source or directly from the Board's Division of Research and Statistics.

The most important of these obstacles may be listed as overenthusiasm of its supporters and administrators which led the public to expect too much in the way of swift assistance in the existing emergency, public misunderstanding of its purposes (strengthened by the direct loan provision), legal obstacles to membership and borrowing in many states, lack of interest and cooperation on the part of eligible institutions, and the rapid turnover in the personnel of the Board, occasioned largely by political considerations. 
the membership response was disappointing and there was little activity during the first few months. The early disappointment proved to be premature, however, for the system enjoyed an impressive growth during 1933, and the expansion of operations continued in subsequent years. By the end of June, $193^{8}$, there were $3,953 \mathrm{mem}$ ber institutions, including $\mathrm{I}, 344$ federal associations, 2,562 state associations, 9 savings banks, and 38 insurance companies. Approximately $40 \%$ of the number and $60 \%$ of the assets of building and loan associations of the country are included in the system's membership, but these percentages for other types of eligible institutions are insignificant. It is estimated that during 1937 and 1938 approximately $85 \%$ of all the new lending by federal and state associations throughout the country has been done by members of the bank system.

Through June 30,1938 , a total of $\$ 446,364,316$ had been advanced by the banks, of which $\$ 196,224,937$ remained outstanding. ${ }^{35}$ This represented a slight decline from the peak of $\$ 200,094,628$ in outstanding credit reached at the end of December, 1937. These sums fall far short of the enormous amounts anticipated by some in the beginning. For nearly five years the capital of the banks, which was originally regarded as merely "a small teakettle full of hot water to pour upon the iceberg of frozen home loans," proved sufficient for lending operations, and it was not until April, 1937, that it became necessary to market the first issue of debentures. ${ }^{30}$ Five issues, aggregating $\$ 142,700,000$, have now been sold. The last two issues, however, were mainly for the purpose of refunding the first two, so that only $\$ 90,000,000$ of debentures remain outstanding. ${ }^{37}$

The interest rate of $5 \%$ which was charged by all the banks until May, 1934 , has been reduced, and for several years the banks have been lending to their members at rates ranging from $3 \%$ to $3 \frac{3}{4} \%$. In spite of these low rates, however, the banks have been able to pay their own expenses, ${ }^{38}$ the deficits incident to organization were wiped out by the end of 1934 , and all the banks have established reserves in excess of those required by law, and have been paying dividends for several years. ${ }^{38}$ Total dividends paid through June 30,1938 , amounted to $\$ 10,296,706$, of which $\$ 8,184,587$

\footnotetext{
$\approx$ Practically all of this money has gone to member institutions. Only threc loans, aggregating \$0,000, were made directly to home owners, all by the Los Angeles bank, and these had been repaid by the end of 1937. The authorization for loans to non-members on the security of insured mortgages has also been practically unused. Something over $\$ 100,000$ has been advanced to non-members by the Los Angeles and Pittsburgh banks, but less than $\$ 3,000$ of this amount rcmains outstanding. Of the outstanding credit nearly two-thirds is in the form of long-term (usually ro-year) amortized loans, and the rest in secured ind unsecured loans for one year or less.

${ }^{30}$ It should be remembered, however, that the "hot water" was supplied in gencrous quantities by the I IOLC and that the banks have been functioning, not as the temporary relief agencies which many of their sponsors apparently wished to make of them, but as a permanent reservoir of credit to be drawn on by incinber institutions for normal business needs.

${ }_{n 7}$ The first two issues, offered in April and July, 1937, and aggregating $\$ 52,700,000$, were for terms of slightly less than one $y$ ear and bore interest rates of $11 / 2 \%$ and $1 \frac{1}{4} \%$ respectively. The next two issues, offered in November, 1937, and March, 1938 , bear interest at $2 \%$ and have terms of three and five years respectively. The last issue, maturing one year from July 1,1938 , carries an interest rate of $1 \%$. All issues have been over-subscribed at par or above, and the last sold at a yield of $.435 \%$.

${ }^{80}$ Including their assigned proportion of the Board's expenses.

$\rightarrow$ Dividend rates range from $1 \%$ to $2 \%$.
} 
went to the federal government. As these figures indicate, approximately four-fifths of the system's capital has been supplied by the government, and this percentage is being reduced very slowly by increased stock holdings of members. The early hopes of the Board and of Congressional sponsors of the law that most of the capital would be supplied by members were patently illusory, and the conclusion is inescapable that the government must remain indefinitely as a stockholder in the system. ${ }^{40} \mathrm{It}$ has earned approximately $\mathrm{r} 1 / 2 \%$ on this investment. Since this rate is below the rate the government pays for long-term money, the banks are subsidized to this extent.

\section{Refinancing by the Home Owners' Loan Corporatton}

In contrast with the glowing predictions of the benefits that would be immediately derived from creation of the bank system, nothing in particular happened, and the urban mortgage situation became worse instead of better. Foreclosures on urban homes continued to mount until by June, 1933, they were occurring at the record rate of about 800 a day. It was apparent that the small amount of funds being advanced by the banks, which was being used almost exclusively to meet withdrawal demands of building and loan shareholders, could do little to relieve the existing situation. The new administration, therefore, and the new members of the Board whom it appointed, proposed and sponsored creation of the Home Owners' Loan Corporation and piloted the necessary legislation through Congress. This legislation was proposed in a message by President Roosevelt on April 13, 1933, in which he said:

Implicit in the legislation which I am suggesting to you is a declaration of national policy ... that the broad interests of the Nation require that special safeguards should be thrown around home ownership as a guarantee of social and economic stability, and that to protect home owners from inequitable, enforced liquidation in a time of general distress is a proper concern of the Government. ${ }^{41}$

There was practically no opposition to the measure in Congress, although details were criticized by some members as being too liberal and by others as being too conservative. In line with the tenor of the times, action on the bill was expedited. It was passed by a vote of 383 to 4 in the House on April 28, approved unanimously by the Senate on June 5, and signed by the President on June 13 , just two months after his original proposal.

Provisions of the Law. The Act provided for creation of an instrumentality of the United States to be known as the Home Owners' Loan Corporation, directed by the members of the Federal Home Loan Bank Board and capitalized at $\$ 200,000,000$, all of which was to be subscribed by the Secretary of the Treasury and paid by him at the call of the Board with funds obtained from the RFC. The Corporation was authorized to issue bonds not exceeding 18 years in maturity, $4 \%$ in interest, or $\$ 2,000,000,000$ in total amount. The interest, but not the principal, of these bonds

\footnotetext{
${ }^{\star}$ In its Third Axivual Report (1936), at p. 8, the Board states: "There is no apparent reason why the Government should retire its investment."

a7 CoNG. Rec. 1618 (1933).
} 
was guaranteed by the government, ${ }^{42}$ and they were exempt from all taxation except surtax, estate, inheritance, and gift taxes.

For a period of three years the Corporation was authorized to acquire mortgages in three different ways: (I) It might exchange its bonds for home mortgages and other similar obligations executed prior to the date of the Act. In connection with such exchanges it might also advance cash when necessary for the payment of taxes, assessments, maintenance, repairs, expenses of the transaction, and odd amounts necessitated by the even denominations of its bonds. The total amount of bonds and cash thus advanced in connection with an individual mortgage was limited to $\$ 14,000$ and to $80 \%$ of the value of the real estate as appraised by the Corporation. Interest to be charged by the Corporation on mortgages acquired in this way was limited to $5 \%$. (2) If the holder of an eligible mortgage would not accept the Corporation's bonds, and if the home owner could not obtain a loan from ordinary lending agencies, the Corporation was authorized to advance cash, at a rate of interest not exceeding $6 \%$, up to $40 \%$ of the value of the property. (3) On property not otherwise encumbered, the Corporation might advance cash, at a rate not exceeding $5 \%$, up to $50 \%$ of the value of the property, for payment of taxes, assessments, maintenance, and repairs.

In order to be eligible for acceptance by the Corporation, an obligation had to be a first lien on a dwelling or dwellings for not more than four families having a value of not more than $\$ 20,000$ and used in whole or in part by the owner as a home or held by him as his homestead. ${ }^{43}$ The Corporation was specifically authorized to exchange its bonds and advance cash to permit former owners to recover homes lost by foreclosure, forced sale, or voluntary surrender to mortgagees within two years prior to such exchange or advance. All obligations to the Corporation were to be retired by amortization over a period not exceeding fifteen years, but the Act required that a three-year moratorium be granted on principal payments and permitted the granting of other extensions of time for payments of principal and interest.

Changes in the Law. In its original form the law did not require that mortgages accepted should be in default or that the mortgagor should give any proof of his inability to meet his payments. ${ }^{44}$ This failure to limit operations to distress cases caused difficulties, and the amendment of April 27, x934, prohibited the Corporation from making any exchange or advance unless the applicant was in involuntary default on the date of passage of the original law and was still unable to carry his indebtedness, or unless the Corporation found that a default after that date

\footnotetext{
2 Although the wording of the law was not specific, many legal authorities believed this was a continuous guarantee, which would apply even after the maturity date in event of default. See, e.g., ANNnLs, 1933, p. 233.

It should be noted that the law did not limit operations of the Corporation to urban real estate, although actually its operations were limited to non-farm homes in practice.

"It has been claimed that this was an unintentional omission, but this is hardly conceivable, and as a matter of fact the Senate committee turned down a suggestion that a provision be inserted limiting loans to those persons in financial distress at the time of passage of the law. AnNals, 1933, p. 284; 1934, p. 590.
} 
was due to unemployment or conditions beyond the control of the applicant.45 The same Act further reduced the attractiveness of the Corporation's credit facilities by repealing the requirement for a three-year moratorium on principal payments and making the granting of extensions of time for both principal and interest payments a matter of discretion with the Corporation's officials. The field of the Corporation's operations was expanded by this Act, however, in two respects. It was authorized to make advances for the recovery of homes lost subsequent to January I, 1930, instead of having to confine such advances to homes lost within two years preceding the advance. A fourth type of lending operation was also authorized with the provision for cash advances not exceeding in the aggregate $\$ 200,000,000$ and bond exchanges, in connection with and subject to the limitations governing the other three types, for purposes of rehabilitation, modernization, rebuilding, and enlargement of any homes financed by the Corporation. ${ }^{46}$

The most important changes in the law related to the Corporation's bonds. The guarantee of interest only did not prove sufficient to give the bonds a market at par, ${ }^{47}$ and, at the request of the Board and the President, Congress, in the Act of April 27, 1934, went the rest of the way and guaranteed the principal as well.48 Two months later the authorized amount of the bond issue was increased to $\$ 3,000$, 000,000 , and in the Act of May 28, 1935, the final limit was placed at $\$ 4,750,000,000$. On November 16, I934, the Board, at the earnest solicitation of lending institutions, ${ }^{49}$ which contended that they were suffering from defaults by applicants who could not reasonably expect to receive assistance from the Corporation, had

${ }^{*}$ It was originally provided that this limitation should not apply to liens held by financial institutions in liquidation. This exception was removed by the Act of May 28, 1935.

* The amount of cash available for this purpose was increased to $\$ 300,000,000$ by the Act of June 27 , 1934, and increased again to $\$ 400,000,000$ by the Act of May 28, 1935, although only about half of the original amount provided has been utilized.

17 The bonds were first issued and listed on the New York Realty Exchange in September, 1933. Their quoted price steadily declined as the supply increased to a low of $821 / 4$ on November 16 and remained below 85 until the end of the year, but there was a very small volume of trading. After the President's announcement on January 5, 1934, that he would ask Congress for a guarantee of the principal, the market quotations advanced gradually and reached par when the law was passed on April 5 .

In connection with many of the bond cxchanges made during this period, the mortgagor was forced by the mortgagee to give a promissory note or cash consideration for the difference between the markct and par value of the bonds accepted. There is some evidence that the Board originally sanctioned this practice or that lending institutions thought it did. (1934) 54 AM. BLDG. Ass'N News 136 . But the Board later took the position that it was illegal under the existing law, that the notes given were not enforceable, and that mortgagees requiring such consideration were subject to criminal prosecution. See testimony of Horace Russell in Hearings of the House Banking and Currency Committee on H. R. 8403, 73rd Cong., 2d Sess. (1934). In the Act of May 28, I935, long after all reason for the practice had been removed, the law was amended so as to make it definitely illegal.

${ }^{4}$ Holders of the $4 \%$ bonds, which had previously been issued to the amount of $\$ 63 \mathrm{r}, 840,450$, were given the option of exchanging them within six months for the fully guaranteed bonds, interest on which was fixed originally at $3 \%$. The interest rate was reduced to $23 \% 4 \%$ on subsequent issues of bonds offered in exchange for mortgages, and some bonds were later sold at rates of $2 \%, x 1 / 2 \%$, and $11 / 4 \%$.

Other changes relating to the Corporation's bonds, which were made at the time their principal was guaranteed, limited their final maturity date to $I 952$ and wrote into the law a requirement previously adopted by resolution of the Board (see its FIRST Annua Report [1934], p. 50) that all payments to the Corporation on the principal of loans should be applied to retirement of its bonds.

${ }^{20}$ Annals, 1934, p. 472. 
announced that no more applications would be received and that consideration from then on would be limited to those "in which the eligibility had been established and all preliminary work done with the exception of preparing the titles and closing the loans."50 This action provoked' a good deal of criticism, and in making the final increase in the authorized bond issue Congress provided that applications should be received for an additional period of thirty days.

Extent of Operations. More than a third of the existing urban home mortgage debt was at one time or another the subject of an application to the HOLC. Total loans applied for numbered $1,886,693$ and amounted to $\$ 6,172,647,600$, which is more than half of the estimated debt on owner-occupied urban homes in the United States. When the Corporation's lending life expired by limitation of the original law on June $\mathrm{I}_{3}, \mathrm{x}_{93} 6$, it had acquired $1,018,390$ mortgages totaling $\$ 3,092,870,784$, accepting more than half of the applications filed. More than $99 \%$ of these loans were made in the form of bond exchanges. The Corporation is now entirely a liquidating organization engaged in the service and collection of its loans and the management of acquired property. In spite of a lenient policy, it has found a large number of foreclosures necessary and has already become a landlord on a very large scale. Through June 30, 1938, foreclosure proceedings had been instituted on about $15 \%$ of the properties mortgaged to the Corporation. Title to 99,948 properties had been acquired, and 16,553 additional properties had been bought in at foreclosure sale and were awaiting expiration of the redemption period, making a total of nearly $12 \%$ of the properties originally mortgaged to the Corporation. The unpaid principal of mortgages foreclosed amounted to $\$ 487,191,512$, which is more than the total amount of principal payments collected by the Corporation at that time, and about $x 6 \%$ of the total amount lent. On the same date 17,532 of the foreclosed properties had been sold at a loss of $\$ 7,749,214$. The Corporation is currently collecting between $85 \%$ and $90 \%$ of the amount of the monthly installments due, but about one-third of its borrowers are three months or more delinquent in principal and interest payments.

Approximately one-sixth of the urban home mortgage debt of the United States was taken over by the HOLC. It originally held a mortgage on one out of every ten owner-occupied urban homes and has now acquired title to many of these homes. The vast volume of indebtedness represented by these mortgages is owed for the most part by individuals who have demonstrated their inability to repay it. It has been acquired with funds which the United States government has promised to repay. The question naturally arises as to how much loss the taxpayers may expect to suffer. In spite of the original assurances by some of the Corporation's officials to the contrary, it seems certain that there will be some. No one, however, can accurately predict at present how great this loss will be. It seems logical to

\footnotetext{
${ }^{\infty}$ Second Annual Report (1935), p. 82. It was said that there were at the time more than enough applications in this category to use up the remaining resources available, which werc a little more than a billion dollars. There was some. feeling at the time, however, that this policy was adopted as a weapon to force Congress to increase the amount of bonds authorized.
} 
suppose, and experience so far demonstrates, that a considerable number of the defaulters of the past will default again in the future. Just how far Congress will permit this agency of the government to go in foreclosing on the homes of its citizens is problematical, but that there will be demands for further prodigality is certain. If such demands prevail; the loss sustained may be very great. If not, the Corporation may be able to terminate its existence at only moderate cost to the taxpayers.

\section{SHARE INVESTMENT}

When the establishment of federal savings and loan associations was authorized in the Act of June I3, I933, as described in the succeeding section, provision was made for the investment of federal funds in these associations. The Secretary of the Treasury was directed to subscribe, upon the request of the Board, ${ }^{51}$ for shares in them, which were to be preferred as to assets but not as to dividends. The investment by the government in an individual association was limited to $\$ 100,000$ and to an amount equal to the amount paid in on shares by all other shareholders. The total amount authorized for such investments was $\$ 100,000,000$, but only $\$ 50$,000,000 of this was actually appropriated. ${ }^{52}$ After five years from the date of investment by the government, the association was required to set aside regularly onethird of its receipts from investors and borrowers for the retirement of preferred shares.

In carrying on the work of setting up federal associations, the Board encountered resistance on the part of private investors to putting their money into an institution in which stock held by the government had a preferred status. It therefore induced Congress to make the fund available, by the Act of April 27, 1934, to the Secretary of the Treasury for investment in preferred or non-preferred fullpaid income shares of the associations. The Board also stated that the limit of $\$ 100,000$ on the investment in an individual association had proved a handicap to the conversion of large institutions to federal charter, and this limitation was removed by the same Act. At the same time the law was further liberalized by the provision that the total investment by the government in preferred and non-preferred shares of an individual association might be as much as three times the total investment by other shareholders. The Board was given the right, after five years from the date of investment, to request associations to retire each year a maximum of $10 \%$ of the amount invested by the government in non-preferred shares.

With passage of the Act of May 28, I935, state-chartered building and loan associations succeeded in getting the privilege of securing share investments extended to them, but only those which are members of the bank system or have their accounts insured are eligible. Investments in state-chartered institutions come from the HOLC rather than the Treasury, and this agency is also authorized to purchase obligations of the Home Loan Banks and, after exhaustion of Treasury funds available for the

\footnotetext{
The Board was to approve requests by associations for such investments only when it found that the funds were necessary for home financing in the community 'served by the institution.

By the Deficiency Act of June 16, 1933 .
} 
purpose, full-paid income shares of federal associations on the same terms and conditions as those previously established for Treasury purchases. Investments of these three types are limited to $\$ 300,000$,000 in addition to the amount previously made available from the Treasury, and the total investments by the HOLC and the Treasury in an individual federal association are limited to three times the amount of the investment by other shareholders. ${ }^{\text {s3 }}$

By October 12, 1935, the Treasury fund available for share purchase had been exhausted, and investment by the HOLC in federal associations began. At the end of June, 1938, \$21r,997,6ro had been invested by the HOLC, of which $\$ 170,995,300$ had gone to federal associations. The amount invested was about $90 \%$ of the amount of requests received by that date from federal associations and about $75 \%$ of the amount requested by state associations. Since September r, 1937, the HOLC has followed the general policy of making no purchases of shares except in rehabilitation cases of extreme need.

\section{Federal Savings and Loan Associations}

It was felt that one reason for the slow start of the bank system was the lack of retail outlets for its credit, and disappointment at the membership response brought discussion of the possibility of giving support to business men who would form new associations in certain sections of the country where existing institutions refused to become members. ${ }^{54}$ This idea reached fruition with passage of the Home Owners' Loan Act, which included the authorization for establishment of federal associations. There was surprisingly little opposition to this portion of the bill proposed by the administration and the Board. The attention of Congress was focused on the major relief aspects of the measure, and very little attention was given to this section of it. ${ }^{.65}$

Provisions of the Law. The Board was authorized, under its own rules and regulations, to organize, charter, examine, and supervise federal savings and loan associations "in order to provide local mutual thrift institutions in which people may invest their funds and in order to provide for the financing of Homes." Under the law charters may be issued only (I) to persons of good character and responsibility; (2) if a necessity exists for such an institution in the community; (3) if there is a reasonable probability of its usefulness and success; and $(4)$ if it can be established without undue injury to properly conducted existing institutions of the same type.

\footnotetext{
Winder the wording of the law (Act of May 28, 1935, \$17 (a)), this latter limitation apparently does not apply to investments in state-chartered institutions, but the intention undoubtedly was to make the terms the same, and the law has been so interpreted.

4 See Business Week, Dec. 28, 1932, p. 13, and (1932) 52 AM. BLDG. Ass'N News 562. At the time creation of the bank system was being considered, attention was given to the proposal for including in the law authorization for federal chartering of associations. Some building and loan leaders regarded the absence of such a provision as a major defect of the bill and felt that no reserve system for building and loan associations could operate successfully with a membership composed of institutions operating under such a wide variety of state laws as existed. AnNıLs, 193 I, pp. 65.75. A committee of the United States Building and Loan League repeatedly endorsed the idea of federal incorporation. Id., 1932, pp. $485-487$.

${ }^{80}$ There were, however, some attempts in Congress to relnove from the bill the authorization for conversion of state associations to federal charter.
} 
All federal associations must become members of the bank system. "To enable the Board to encourage local thrift and local home financing and to promote, organize, and develop the associations herein provided for or similar associations organized under local laws," $\$ 850,000$ has been appropriated. ${ }^{56}$

In addition to chartering new associations, the Board is authorized, under its own rules and regulations, to permit any member of a Federal Home Loan Bank to convert itself into a federal association upon the affirmative vote of $51 \%$ or more of the votes cast at a legal meeting called to considdr such action. The law originally provided that the conversion of an institution might take place only "upon a vote of, its stockholders as provided by the law under which it operates," but the failure of some states to pass enabling legislation led to the change, which was made by the Act of April 27, 1934. This change did not accomplish the purpose sought, however, for the Supreme Court has ruled that this portion of the Act, to the extent that it permits conversion of state associations in contravention of state laws, is "an unconstitutional encroachment upon the reserved powers of the states" under the Tenth Amendment. ${ }^{57}$ Conversions, therefore, must still be in accordance with state law.

Associations may. raise capital only from payments on shares authorized in their charters, no deposits may be accepted, and no certificates of indebtedness may be issued except for borrowed money authorized by the Board. They may lend only on the security of their shares or on first liens upon homes or combinations of homes and business property located within fifty miles of their home office, and not more than $\$ 20,000$ may be lent on the security of any one property..$^{88}$ Any portion of the assets of federal associations may be invested in United States obligations or in stock or bonds of a Home Loan Bank. Federal associations are exempt from all federal taxation and may not be forced by state or local governments to bear a higher burden of taxation than other similar institutions. Their shares are exempt from all federal taxation except surtaxes, estate, inheritance, and gift taxes. Any association

The original amount appropriated was $\$ 150,000$. The Act of April 27, 1934, increased the amount by directing the Secretary of the Treasury to turn over to the Board $\$ 500,000$ of the funds previously made available to him for investment in federal associations. This amount was increased to $\$ 700,000$ by the Act of May 28,-1935. These funds were supposed to be used impartially for promotion of both state and federal associations.

${ }^{6}$ Hopkins Federal Savings and Loan Ass'n v. Cleary, 296 U. S. 3I5 (1935). The Court pointed out that under the wording of the law insurance companies and savings banks could also convert themselves into federal associations without the consent of the state. In this decision, however, it overruled what it said was a dictum in Casey v. Galli, 94 U. S. 673 (I876), rclating to the conversion of a state bank to national charter, on the ground that the same plea of violation of the Tenth Amendment was not invoked in the earlier case.

In the Hopkins case the Court found it unnecessary to decide whether or not Congress has the power to create federal savings and loan associations at all, but a case is now pending before the Supreme Court which directly challenges this power. First Federal Savings and Loan Ass'n v. Loomis. On May 20, 1938, the Seventh Circuit Court of Appeals handed down a two-to-one decision in this case upholding constitutionality of the law: Id., 97 F. (2d) 831.

For an excellent analysis of the question of constitutionality, see the ANNUAL REPORT OF TFE BUILDINo AND LOAN COMMissioner of CALIFornia, 1935, pp. II5-118.

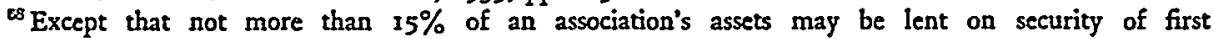
liens on improved real estate without regard to the $\$ 20,000$ or 50 -mile limitations. A further exception, added by the Act of May 28, 1935, permits converted associations to continue to make loans in the territory in which they operated under state charter. 
or other member of the bank system may be designated as fiscal agent of the government or any of its instrumentalities. ${ }^{59}$

Growth of the System. At the end of June, 1938, 1,346 federal associations with approximate assets of $\$ 1,213,874,000$ were in operation. This represented about $15 \%$ of the total number and $22 \%$ of the total assets of all similar institutions in the country. Of the total number, 640 were new and 706 converted associations. New institutions were naturally much smaller than the others, and converted associations held more than three-fourths of the total assets of the system. Growth in the number of federal associations was most rapid during the first year and a half, and the rate of growth has been steadily declining since. By the end of r 934 nearly half of the total number of federal associations now in operation had been chartered. The fact that three-fourths of the present number of new associations had been chartered by that date indicates the pronounced trend in recent years toward growth of the system through conversion of existing institutions rather than through chartering of new ones. ${ }^{60}$ It has frequently been pointed out by those in charge of the program that at the time the law was passed there were 1,566 out of the 3,072 counties in the United States without building and loan facilities. Institutions have now been established, however, in practically all of such counties which are capable of supporting them, and it appears that growth of the system through organization of new associations will be negligible in the future. The policy of the Board definitely favors conversion rather than new chartering. ${ }^{61}$ There appears to be in theory, however, no reason to expect that state associations will be driven from the field. ${ }^{.2}$ Some such development as that in the field of commercial banking may probably be anticipated.

\section{The Federal Savings and Loan Insurance Corporation}

Creation of a corporation to guarantee the investments of building and loan shareholders was the direct result of establishment of the FDIC. ${ }^{33}$ On January 3, 1934, the Board announced that it was studying the question of insurance of shares, impliedly at the request of the President, and a first draft of the proposed legislation

${ }^{t}$ In an attempt, apparently, to strengthen the constitutionality of the law, this authorization was added by the Act of April 27, 1934 .

- The number of new associations now in operation is less than at the end of 1936. Some new associations have been chartered during this period, but the number is reduced from time to time by consolidations or failure to complete organization.

61 See the statement of T. D. Webb (r934) 54 AM. BLDg. Ass'N NEws I67-I68.

Where the direct-reduction plan of lending and the issuance of paid-up and optional payment shares are possible under state laws, state associations can offer everything the federals can, except the prestige of the federal name.

* At the time this organization was being set up, many building and loan officials feared that an in. crease in their withdrawals would result from the desire of investors to transfer their funds to insured accounts in.commercial banks. ANNAIs, 1933, p. 72. There was considerable difference of opinion in building and loan circles, however, concerning the wisdom of sponsoring a similar plan for the protection of their members, and a research bulletin issued by the educational organization of the league in November, 1933, leaned toward the viewpoint that such action was unnecessary. (1933) 53 AM. BLdo. Ass'N News 574. A league committee later endorsed the proposed legislation, but as submitted to Congress, the bill did not include the amendments desired by building and loan interests, and although changes were made before passage which brought it more closely in accordance with their views, the final measure did not meet with their full approval. AnNals, 1934, pp. 471, 562-563. 
was available on January 10. The idea was not received enthusiastically by administration officials in charge of housing legislation, but, largely through the efforts of Chairman Fahey of the Board, was included as Title IV of the bill which eventually became law under the name of the National Housing Act on June 27, 1934.

Provisions of the Law. The law provided for creation of the Federal Savings and Loan Insurance Corporation, an instrumentality of the United States operating under the direction of a Board of Trustees composed of members of the Federal Home Loan Bank Board and having a capital of $\$ 100,000,000 .{ }^{64}$ Insurance of accounts was made compulsory for all federal associations and available to all similar state-chartered Institutions which would agree to abide by detailed rules and regulations of the Corporation governing specified phases of their operating policies. ${ }^{65}$ The premium for insurance was fixed at $1 / 4 \%$ of the total amount of all accounts of insured members in an insured institution plus the amount of the institution's creditor obligations, and the Corporation was given the right to require payment of an additional premium of equal amount each year if necessary to cover losses and expenses. The law required that the regular annual premium be paid until a reserve fund had been established by the Corporation equal to $5 \%$ of all insured accounts and creditor obligations of insured institutions; and that if the reserve should later fall below this amount, payment of this premium should be resumed. ${ }^{66}$ An "insured member" was defined as an individual, partnership, association, or corporation holding an insured account, and the aggregate protection to each such member was limited to $\$ 5,000 .^{.67}$ It will be noted, however, that the base for calculation of the premium is the total amount of all accounts of insured members, rather than the insured portion of these accounts.

The amount of the insured accounts, as determined by the Corporation, becomes payable upon default by an insured institution, ${ }^{88}$ and "default" is defined as "an adjudication or other official determination ... pursuant to which a conservator, receiver, or other legal custodian is appointed for an insured institution for the purpose of liquidation." Since shareholders have no legal right to secure repayment of

${ }^{\text {a }}$ An ingenious method of providing this capital without cost was devised, under the terms of which the stock was purchased by the HOLC, payment being made in its bonds; on this stock the Insurance Corporation is required to pay cumulative dividends at a rate equal to the interest rate on the bonds.

The Corporation was authorized to reject an application for insurance if it found the character of the management of the applicant or its home financing policy inconsistent with economical home financing or with the purposes of the Act, and was required to reject an application of an institution with impaired capital or with an unsafe management or financial policy.

${ }^{\infty}$ An applicant for insurance after the first year of operation was required to pay an equitable admission fee fixed by the Board on the basis of the reserve fund previously accumulated.

"7 For the legal division's interpretation of this provision, see (1937) 3 F. H. L. B. REv. 187-r89.

${ }^{*}$ It should be noted that this provision might be interpreted in such a way as to provide no protection whatever. The holders of the insured accounts are stockholders. Profits previously apportioned to the stock may be reclaimed when losses occur, and in determining the amount of insurance to be paid, the Corporation might deduct from the book value the anticipated losses in liquidation. As a matter of fact, it was expected at first that this would be the policy. See a discussion of the point by Joseph Sundheim (1935) 55 AM. BLdG. Ass's News 216. On Oct. 3, 1935, however, the Board adopted a resolution stating that the amount of each insured account would be determined without regard to the actual value of the assets of the insured institution. FSLIC, "Rules and Regulations for Insurance of Accounts" (rev. ed., Aug. 21, 1936) §18 (b); (1935) 2 F. H. L. B. REv. 31. 
their investments on demand and a failure to meet requests for withdrawals does not constitute default, it will be seen that the plan does not attempt to guarantee the liquidity, but only the ultimate safety, of investments in insured institutions. ${ }^{00}$ The law provides that the amount of the insured accounts shall be payable, at the option of the member, either (I) with a new insured account in an insured institution not in default or (2) up to $10 \%$ in cash and the balance in negotiable non-interest-bearing debentures of the Corporation, one-half payable one year and the other half three years from the date of default. The Corporation must be appointed as receiver or conservator for all federal associations in default, and may also serve in the same capacity for state-chartered insured institutions when appointed by state authorities.

For violation of the law or of any rules and regulations made in accordance with it, the Corporation has the right, after ninety days' written notice, to terminate the insured status of an institution. If this is done, insured accounts of members existing on the date of termination remain insured for a period of five years, and the institution is required to continue payment of premiums during this period. The law also gives an insured institution the right, after ninety days' written notice and upon vote of a majority of its shareholders or board of directors, to terminate its insured status. $^{70}$ If an institution takes such action, all rights of its members to insurance immediately cease, but its obligation to pay premiums continues for a period of three years.

Changes in the Law. The chief objection of building and loan associations to the terms of the law in the beginning was the cost of insurance. As enacted, this section of the law represented a compromise between the position of the associations and that of the administration, ${ }^{71}$ but the associations regarded the premiums as excessive, since they were much higher than those required of banks ${ }^{72}$ and far in excess of

Another point of contrast with the insurance of accounts in commercial banks should also be noted. In the case of banks, the management has a share in the possible loss that may result from its conduct of the business, because the stockholders stand to lose the amount of their investments. In the case of building and loan associations, which usually do not have non-withdrawable capital stock, it is the stockholders who are protected, and the investments of officers, whose policies may have caused or contributed to the institution's failure, will be paid in full up to the limit of insurance provided.

${ }^{70}$ The Board has ruled, however, that in considering applications for insurance it will not consider them consistent with the purposes of the law unless they contain an agreement, along with the others required by the law, to abide by the detailed rules and regulations prescribed by the Board concerning notification of shareholders and other matters connected with the application for termination of insurance. FSLIC, "Rules and Regulations for Insurance of Accounts," \$2I (a). This would seem to be a rather strained interpretation of $\$ 403$ (c) of the law, the provisions of which are stated supra, note 65 . At the same time, the procedure specified by the Corporation appears desirable. The question is whether it has the right under the law, which makes no mention of rules and regulations in connection with termination of insurance, to impose this procedure as a requirement. Eligible institutions have objected strenuously to this requirement as exceeding the powers of the Board and have contended that it makes withdrawal virtually impossible. See AnNaxs, 1935, pp. 337, 628-629.

${ }^{7}$ In the amendments advocated by the associations, mentioned stupra, note 63 , they had sought to apply the principle of apportioning the premium according to the risk involved by having it arranged on a sliding scale, ranging from $\mathrm{I} / 5$ to $3 / 5$ of $\mathrm{I} \%$ of the insured liability plus creditor obligations, according to the reserves of the insured institution. The administration bill provided for a premium of $1 / 2 \%$ and a possible additional assessment of $1 / 4 \%$ of total withdrawable accounts plus creditor liabilitics. Anmats, 1934, pp. 594-595.

The lower premiums for banks are supposed to be justified by the cushion against loss provided by their capital and surplus. On the other hand, premiums paid by building and loan associations are based on a much higher proportion of total assets. 
the reported loss experience of associations in the past. ${ }^{73}$ In addition to the premium, the original law required that insured institutions build up a reserve equal to $5 \%$ of total insured accounts within a period of ten years and prohibited payment of dividends in any period for which losses were chargeable to this reserve. Under this law, therefore, premiums, assessments, and reserve allocations might have aggregated annually as much as $1 \%$ of resources, which was about the usual margin for total operating expenses, and many associations felt that the necessary reduction of dividends would have been greater than the benefits of insurance justified. In order to make the plan more attractive to them, the Act of May 28, I935, cut the maximum percentages for premiums and assessments in half ${ }^{74}$ and provided for accumulation of the required reserve over a period of twenty years instead of ten. It also permitted institutions, with the approval of the Corporation, to pay dividends for periods in which losses were chargeable to this reserve. ${ }^{75}$

Extent of Operations. The response of state-chartered institutions to the insurance program was not great until after the amendments of May, 1935. Since then, however, the percentage of total insured institutions represented by them has been steadily increasing. At the end of June, 1938 , there were 2,014 insured institutions, divided about equally between state-chartered, new federal, and converted federal associations. State-chartered institutions held nearly two-fifths of the $\$ 1,978,476,000$ total assets and had nearly half of the $1,919,000$ shareholders in all insured institutions. The 678 state-chartered members, however, constituted only about $8 \%$ of the total number, $15 \%$ of the total assets, and $18 \%$ of the number of shareholders in all state-chartered building and loan associations in the United States. These percentages for all insured institutions, compared with all institutions in the country of the types eligible for insurance, were about $20 \%, 35 \%$, and $30 \%$ respectively.

\section{The Federal Housing Administration}

Creation of the Federal Housing Administration was proposed to Congress in a special message by the President on May I4, $1934{ }^{78}$ Support for the proposal came from practically every interested group-labor organizations, builders, equipment and supply manufacturers, dealers, and finance agencies, real estate associations, etc., in addition to financial institutions. There was practically no opposition to the bill as a whole, ${ }^{77}$ and action by Congress was even more speedy than on the Home Owners'

\footnotetext{
${ }^{73}$ For the published figures on estimated losses in building and loan failures since 1920, see ANNaLs, 1937, P. 367 .

II Institutions which had previously paid the higher premiums were granted credit of the excess amount on future premiums.

${ }^{75}$ The same law provided a more equitable method of distribution of any surplus remaining after liquidation of an insured institution, and permitted the Corporation to makc contributions or loans to or purchase assets of an insured institution in order to prevent default or to restore the institution to normal operation after default.

${ }^{70} 78$ Cong. REc. $8739-40$ (1934). For a summary of the proposed legislation, see the National Emergency Council's press release of May 14. New York Times, May 15, 1934, p. I.

77 There was opposition, however, to some sections of the bills reported by the committees from members of Congress who thought they did not go far enough in providing government funds for slum clearance and low cost housing projects. There was also opposition, led by building and loan associations and
} 
Loan Act. Final approval was given by both houses on the last day of the session, June 18 , and the bill became law with the President's signature on June 27. From the original proposals and the Congressional debates it is apparent that the law was designed primarily to stimulate revival of the construction and durable goods industries, improve mortgage lending practice, strengthen financial institutions, and make possible increased use of bank funds in real estate financing without impairing the liquidity of such institutions, rather than to provide more adequate housing for the low-income groups.

Provisions of the Law. The Act provided for creation of a Federal Housing Administration, with all powers vested in an Administrator, who is appointed by the President with the advice and consent of the Senate for a term of four years. The RFC was directed to make available to the Administrator whatever funds he found necessary, and its authorized bond issue was increased by an amount sufficient to provide such funds. The President was also authorized to make allotments to the Administrator from any funds available to him for emergency purposes. ${ }^{78}$ Contrary to a popular impression which has been difficult to dispel, the FHA does not lend any money. ${ }^{79}$ Its distinctive function is to insure lenders against losses which they may sustain on certain types of loans. These insurance activities fall into two major divisions, usually designated as Title I and Title II loans.

Under Title I three types of loans are eligible for insurance: ${ }^{80}$ ( 1 ) Title I is principally concerned with loans for financing alterations, repairs, and improvements on existing structures. ${ }^{81}$ To be eligible for insurance, such loans must not exceed $\$ 10,000{ }^{82}$ (2) While the original intention in this part of the law was to provide increased credit for these purposes, the wording was broad enough to cover loans for new construction also. The wording was changed by the Act of April 3, r936, so as

other financial institutions, to portions of the proposed legislation which they thought went too far in providing for subsidized competition with private lending agencies, and this opposition led to modification of the original proposal by Congress. See the House and Senate debates, 78 Conc. Rec. xriz8-224, I1363-94, I1973-76 (1934).

${ }_{78}$ By the Act of June 22, 1936, however, the Administrator and the other agencies previously described, along with others, were forbidden to incur any administrative expenses after June 30,1937 , except pursuant to specific annual appropriations by Congress.

"action 3 of the original Act, which authorized loans to institutions insured under Title I upon the security and up to the full face value of obligations meeting the requirements for Title $I$ insurance, was repealed by the Act of April 3, 1936.

${ }^{80}$ Insurance under Tile I was originally limited to loans, advances of credit, and purchases of obligations representing such loans and advances, made prior to Jan. I, 1936. By the Act of May 28, 1935, the authorization was extended to April I, 1936, and by the Act of April 3, 1936, to April I, 1937, when it expired. It was revived and extended to July I, 1939, by the Act of Feb. 3, r938. In each case it was provided that the President might terminate Title $I$ insurance at an earlier date than that specified in the law.

${ }^{81}$ By the Acts of May 28 and Aug. 23, x935, loans for financing the purchase and installation of machinery and equipment were included in this authorization, but this provision was removed by the Act of April 3, 1936.

62 The limit was originally $\$ 2,000$. An exception, permitting insurance of loans up to $\$ 50,000$ for such financing of property improved by or to be converted into apartment or multi-family dwellings, hotels, office, business, or other commercial buildings, manufacturing or industrial plants, hospitals, orphanages, colleges, schools, or churches, was added by the Act of May 28, 1935. This exception was removed and the limit increased to $\$ 10,000$ by the Act of Feb. 3, 1938 . 
virtually to eliminate the insurance of such loans under Title $1,{ }^{83}$ but in the Act of February 3, r938, the original wording was restored, and it was specifically provided that loans for new construction might not exceed $\$ 2,500$. (3) The insurance of catastrophe loans $^{84}$ was first authorized by the Act of April 17, 1936. Such loans must not exceed $\$ 2,000$. $^{85}$

The total amount of insurance granted to an institution on the first two types of loans is limited to $10 \%$ of the total amount of such loans, advances of credit, and purchases made by it. ${ }^{88}$ On the third type the limit is $20 \%{ }^{87}$ The total amount of liability which the Administrator may have outstanding at any one time plus the amount of claims paid on loans insured under Title $I$ is limited to $\$ 100,000,000 .^{88}$ There is no charge for insurance under Title $I$, and all losses are paid by the government. Except for the maximum limits, Title $I$ is practically devoid of restrictions concerning the granting of insurance. Loans to be insured are not limited to residential structures or to urban areas. ${ }^{89}$ The Administrator is given complete authority to prescribe the conditions under which lending agencies will be approved for insurance and to specify the requirements concerning interest rates, maturity, security, and" other conditions to which their loans must conform.

Under present regulations, only loans in excess of $\$ 2,500$ require prior approval of the Administrator. ${ }^{90}$ The local lending institution is the sole judge of the wisdom of extending credit of less than this amount and simply reports its eligible loans for insurance within thirty-one days after they are granted. No down payment and no mortgage or other security is required, even on loans for new construction, ${ }^{\text {a1 }}$ but local institutions are free to require security or endorsers if they wish. Loans to finance new structures intended in whole or in part for residential use may have a maturity not in excess of seven years and an interest yield not exceeding $6.69 \%$ (\$3.50

\footnotetext{
es The original wording was "alterations, repairs, and improvements upon real property." This was changed to "alterations, repairs, and additions upon improved real property."

* I.e., loans made for the purpose of financing restoration or replacement of improvements on real property, equipment, and machinery damaged or destroyed by flood, tornado, earthquake, or other catastrophe in the years 1935 to 1939 inclusive. The authorization originally expired Jan. 1, 1937, and provided that the damage or destruction must have taken place in $x 935$ or 1936. It was revived and extended to July I, 1939, by the Act of April 22, 1937.

Except on the types of structures enumerated in note 82, supra, where the limit is $\$ 50,000$.

${ }^{\infty}$ At the request of the Administrator, this was reduced from $20 \%$ by the Act of April 3, 1936 .

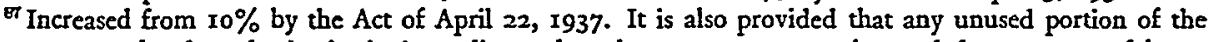
reserve accumulated to the institution's credit on the other two types may be used for payment of losses sustained on this type of loan.

${ }^{8}$ The original law limited the total insuranco liability which might be incurred to $\$ 200,000,000$. At the request of the Administrator, this was changed to $\$ 100,000,000$ by the Act of April 3, 1936. The wording was changed by the Act of Feb. 3, 1938, so as to make the limit applicable to the total liability at any one time rather than to the total amount of liability incurred.

${ }^{8}$ There has never been any such limitation, but the Act of Feb. 3, 1938, made the cligibility of loans outside cities specific by addition of the words "urban, suburban, or rural."

${ }^{\infty} \mathrm{Nev}$ residential structures must conform to certain minimum construction requirements and require prior approval as to location.

${ }^{81}$ Except on such loans having a maturity in excess of 5 years, in which case a first lien is required. Even this requirement is waived, however, in the case of institutions publicly supervised and prohibited from making secured loans equal to the full vaiue of the structure.
} 
discount per $\$ 100)$. On other loans the insurance is limited to a period of five years and the interest yield to $9.72 \%$ ( $\$ 5$ discount per $\$ 100$ ).

Title II provides for a system of mutual mortgage insurance under which the Administrator is authorized to insure, or to make commitments to insure prior to execution, fully amortized loans secured by property of three types: (I) Owneroccupied dwellings designed principally as single-family residences. The construction of such dwellings must have been begun after February 3, 1938, and the mortgage must have been approved for insurance prior to the beginning of construction, or, if construction was begun between January $x$, 1937, and February 3, 1938, the dwelling must not have been sold or occupied since completion. The mortgagor must have paid on the property at least $10 \%$ of the appraised value in cash or its equivalent, and the mortgage must have a maturity not exceeding 25 years. ${ }^{92}$ The principal of such mortgages is limited to $\$ 8,600$ and may not exceed $90 \%$ of the appraised value up to $\$ 6,000$ plus $80 \%$ of the appraised value in excess of $\$ 6,0000^{03}$ (2) Dwellings designed principally for residential use for not more than four families. Mortgages on such property must not exceed $\$ 16,000$ or $80 \%$ of the appraised value $^{94}$ and must have a maturity not exceeding 20 years. (3) Rental housing projects covered by mortgages up to $\$ 5,000,000$. The original Act contained a simple authorization for insurance up to $\$ 10,000,000$ on projects designed to provide housing for persons of low income. The Act of February 3, 1938, added detailed regulations covering this type of insurance and provided for creation of a separate fund, known as the Housing Insurance Fund, in connection with it. Since this type of insurance is dealt with in a later article, ${ }^{95}$ it will not be described here. While many of the provisions are the same, the following discussion relates only to mortgages of the first two types.

First liens made to and held by approved mortgagees, containing complete amortization provisions and other terms prescribed by the Administrator, bearing interest, exclusive of premium and service charges mentioned below, at a rate not exceeding $5 \%,{ }^{98}$ and executed in connection with projects which the Administrator considers economically sound, are eligible for insurance. ${ }^{97}$ Mortgages of the second

\footnotetext{
${ }^{2}$ On mortgages for more than $\$ 5,400$ the maximum maturity is 20 years. Since the 1938 amendments all maturities are reckoned from the date of insurance, rather than the date of execution, of the mortgage.

The provisions covering this type of property were added by the Act of Feb. 3, 1938, and mortgages of this type for $\$ 5,400$ or less were given several types of favorable treatment. In addition to the longer maturity mentioned above, the premium rate was fixed at $1 / 4 \%$ on such mortgages accepted for insurance prior to July 1, 1939, mortgagees were permitted, in the event of default, a special allowance of as much as $\$ 75$ for foreclosure costs under certain conditions, and it was provided that the Administrator's expenses in connection with such mortgages should be charged to the reinsurance account, which means that they are paid entirely from government funds.

${ }^{2}$ Since the 1938 amendments appraisals are supposed to reflect the value as of the date the mortgage is aecepted for insurance; previously, the value on the date of execution of the mortgage was to be considered.

${ }^{\infty}$ Brabner Smith, The Financing of Large-Scale Rental Housing, infra, p. 608.

${ }^{\infty 0}$ Or $6 \%$ if the Administrator finds that in certain areas the mortgage market demands it. In practice, at the request of the President, the rate has been limited to $5 \%$ since June 24,1935 .

${ }^{93}$ Until the Act of Feb. 3, 1938, the mortgage had to be offered for insurance within one year of its exccution.
} 
type mentioned in the preceding paragraph may cover either new or existing structures. The $193^{8}$ amendments, however, provide that beginning July I, I939, no mortgages may be insured unless they cover property (I) approved for mortgage insurance prior to completion of construction; or (2) the construction of which was commenced after January I, I937, and completed prior to July I, 1939; or (3) previously insured by the Administrator. The law has never limited insurance operations to urban mortgages, but the $193^{8}$ amendments specifically provide for the insurance of otherwise eligible mortgages covering farms on which houses or buildings are to be constructed or repaired, providing at least $15 \%$ of the principal of the mortgage is to be spent for materials and labor.

The Administrator is authorized to collect an annual premium charge for insurance of from $1 / 2 \%$ to $\mathrm{r} \%$ of the amount of the principal obligation outstanding, without taking into account delinquent payments or prepayments. ${ }^{98}$ The Administrator requires payment of these premiums in advance by the mortgagee, who collects them from the mortgagor. Authorization for the annual service charge of $1 / 2 \%$ of the outstanding principal formerly permitted by the Administrator was removed from the regulations in February, I938. If default occurs on an insured mortgage, the mortgagee is permitted to foreclose or acquire title to the mortgaged property by other means, and upon delivery of acceptable title to the Administrator is entitled to receive debentures equal in face value to the value of the mortgage. ${ }^{90}$ These debentures are issued in the name of the Mutual Mortgage Insurance Fund, are fully

\footnotetext{
${ }^{\text {sa }}$ Prior to the 1938 amendments, this premium was to be fixed according to the risk involved at from $1 / 2 \%$ to $1 \%$ of the original face value of the mortgage. In making this reduction, Congress provided that the new method of calculation should also apply to mortgages previously insured. See also note 93, supra. -In practice, the minimum premiums permitted by law have been charged. The change, together with the elimination of the service charge, has substantially reduced the effective interest rate to the borrower.

In addition to premiums, the Administrator requires an appraisal fee of $\$ 3$ per $\$ 1,000$ of mortgage principal, with a minimum of $\$ 10$, and permits mortgagees to collect an initial service charge of $1 \%$ or $\$ 20$ on loans covering existing structures and $2 \frac{1}{2} \%$ or $\$ 50$ on loans for new construction.

${ }^{\circ}$ The value of the mortgage is determined by adding to the principal unpaid on the date foreclosure procecdings were begun or title was otherwise acquired (until Feb. 3, 1938, the date of delivery to the Administrator) the amount of all payments made by the mortgagee for taxes, insurance, special assessments, water rates which are prior liens, and mortgage insurance premiums paid, less any net income received by the mortgagee from the property. A provision specifying the addition of interest on the unpaid principal from the date of beginning foreclosure proceedings to the date of transfer to the Administrator, less any interest received by the mortgagee, was added by the Act of May 28, 1935, and removed by the Act of Feb. 3, 1938. It should be noted that debentures now bear interest from the date of mortgage default instead of from the issuance date, so the mortgagee still receives interest for the intervening period, though at a lower rate. Aside from this, until the latter date only taxes and insurance paid by the mortgagee were to be added to the unpaid principal. See also note 93, supra.

In addition to the debentures, the mortgagee receives a certificate of claim for an amount equal to the difference between the face value of the debentures and the amount the mortgagee would have received if at the time of conveyance to the Administrator the mortgagor had redeemed the property by paxing in full all obligations under the mortgage and a reasonable amount for oxpenses of foreclosure. This certificate is entitled to an annual increment of $3 \%$ simple interest. If the net amount eventually realized by the Administrator from the property exceeds the principal and interest of the debentures, this excess, up to the amount due on the certificate of claim, is paid to the mortgagee, and any excess above this amount is paid to the mortgagor.

If the mortgagee acquires title to property after default but chooses not to transfer it to the Administrator, obligations on both sides cease, and the nortgagor is entitled to an equitable share of the credit balance in the group account to which his mortgage was assigned.
} 
guaranteed as to principal and interest by the United States, are exempt from all taxes except surtaxes, estate, inheritance, and gift taxes, ${ }^{100}$ bear interest at a rate, not exceeding $3 \%$, determined at the time the mortgage is offered for insurance, ${ }^{101}$ and mature three years after the first day of July following the maturity date of the mortgage.

The aggregate principal obligation of all insured mortgages outstanding at any one time is limited to $\$ 2,000,000,000$, but with the approval of the President this limit may be increased to $\$ 3,000,000,000 .^{102}$ Mortgages accepted for insurance must be divided into groups "in accordance with sound actuarial practice and risk characteristics." 103 Separate accounts are maintained for each group. Premium charges and appraisal fees are credited to these group accounts, and the payments on debentures and certificates of claim and the expenses of handling property are charged to them. In addition to the group accounts, a general reinsurance account is set up with $\$ 10,000,000$ of federal funds, which is available to cover deficits in the group accounts. The Administrator may charge his expenses either to group accounts or to the reinsurance account. ${ }^{104}$ When all mortgages in a group have been paid, or when the amount available for distribution is sufficient to pay all mortgages in the group, the Administrator is to terminate the insurance for that group, charge off estimated losses, transfer to the general reinsurance account $10 \%$ of the premiums previously credited to the group, and distribute equitably to mortgagees, for the accounts of mortgagors, the balance remaining in the group account. ${ }^{105}$

Extent of Operations. ${ }^{100}$ During the original period of Title I operations, extending through March, 1937, I,453,332 notes aggregating $\$ 560,713,601$ had been reported for insurance by 6,399 institutions. ${ }^{107}$ From the revival of Title $I$ in Feb-

${ }^{100}$ Originally the government guaranty applied only to debentures issued in exchange for mortgages insured prior to July 1, 1937. This was extended to July 1, 1939, by the Act of Feb. 19, 1937, and was made unlimited by the Act of Feb. 3, 1938. Prior to the latter Act, the debentures were subject to such taxes as the mortgages in exchange for which they were issued would have been subject to in the hands of the holder of the debentures. Any mortgagee entitled to receive debentures prior to enactment of this amendment is permitted to choose a cash adjustment and the more fully tax-exempt debentures bearing the current rate of interest.

${ }^{102}$ The Act of Feb. 3, 1938, requires approval by the Secretary of the Treasury of the rate and other terms of the debentures. Prior to this date, the rate was $3 \%$; since then it has been $23 \%$.

${ }^{300}$ Prior to the 1938 amendments the limit was $\$ 1,000,000,000$ for mortgages on property cxisting on June 27,1934 (the date of the original $A c t$ ) and $\$ 1,000,000,000$ for mortgages on property constructed after that date, but these limits could be increased indefinitely with the approval of the President. The same Act changed the wording so that the limits now apply to the amount of mortgages oustanding at any one time, instead of, as formerly, to the total amount of mortgages insured.

${ }^{200}$ Originally the groups were required to have "substantially similar risk characteristics and similar maturity dates," but this provision proved very difficult to administer and the change was made by the Act of Feb. 3, 1938 .

${ }^{10 s}$ But see note 93, supra.

${ }^{200}$ The amendment mentioned in note 103 made necessary rewriting of the section dealing with termination of insurance. For the previous provisions, sec $\$ 205$ (c) and (d) of the original Act.

${ }^{100}$ Statistics are published monthly by the FHA in its Insured Mortgage Portfolio and annually in the Reports of the Administrator. Unless otherwise stated, all figures have been obtained from these sources or directly from the Economics and Statistics Division.

For an analysis of operations through 1936 , see Weimer, The Work of the Federal Housing AdminisIration (1937) 45 J. PoL. Ecos. 466-483.

${ }^{107}$ Properties improved by these loans were located in all but 30 of the 3,073 counties of the country, but most of the loans were concentrated, of course, in the densely populated regions, and more than half 
ruary through June $3^{0}$, 1938, I06,I7r loans amounting to $\$ 51,293,557$ were insured. On the latter date 71,656 Title I claims aggregating $\$ 16,748,974$ had been paid by the FHA. This amounts to nearly $3 \%$ of the total notes insured, but about half of the dollar volume of defaulted notes had been recovered or reinstated. ${ }^{108}$

Under Title II at the end of June, I938, nearly Ir,000 institutions with more than 3,000 branches had been designated as approved mortgagees and a total of 324,087 mortgages aggregating $\$ 1,333,905,208$ had been accepted for insurance. Of this number, 242,220 for $\$ 997,849,517$ were actually insured, and 246 had been foreclosed by mortgagees. ${ }^{109}$ The Administrator had sold 69 of the foreclosed properties at a net loss of $\$ 40,842$. Debentures totaling $\$ 1,080,733$ had been issued, of which $\$ 919,705$ were outstanding. The net worth of the Mutual Mortgage Insurance Fund was $\$ 20,35$ I,293, about half of which was represented by federal funds. About $56 \%$ of the mortgages insured during 1937 were on new homes. Insurance operations have been increasing rapidly since the liberalizing amendments of February, 1938, and the ratio of new homes to the total has also been increasing. It is estimated that about $40 \%$ of the mortgages insured since that date are eligible for $90 \%$ loans. More than threefifths of the loans insured under Title II have been made by commercial banks.

\section{Devices to Provide a National Mortgage Market}

Since it was expected that the National Housing Act would increase the flow of funds from commercial banks and other lending agencies into mortgage investment, it was considered desirable to attempt to provide some sort of national mortgage market in order that institutions might dispose of such investments when necessary. Liberalization, in the Banking Act of $1935,{ }^{110}$ of the restrictions governing mortgage investments by national banks resulted in additional need for such a market. The insurance of mortgages itself, of course, enhances their marketability, and there has been a considerable volume of trading in such mortgages among approved mortgagees, ${ }^{111}$ but such trading is hindered by the difficulty of establishing contact between institutions desiring to buy and sell. Additional facilities for turning mortgages into cash have therefore been provided.

of the business was done by 59 institutions. Weimer, supra, note 106 , at 472 . About three-fourths of the funds advanced were expended on residential property, single family residences accounting for more than half the total. About $60 \%$ of the amount borrowed was spent on alterations and repairs, and the remaining $40 \%$ for the purchase and installation of machinery and equipment. Approximately $70 \%$ of the funds advanced came from commercial banks.

${ }^{109}$ For an estimate of the probable loss to the federal government on the original Title I program, see Hart, Government Agencies of Credit (1938) I96 ANNals of THE AM. Acad. 162.

${ }^{10}$ These figurcs exclude mortgages on large-scale rental projects.

210 This Act provides that real estate loans may be made by national banks without territorial limitation if secured by first lien on farm, residential, or business property. Such loans may be made for as much as $60 \%$ of the appraised value of the property and for as long as ten years if at least $40 \%$ of the principal is to be amortized within that time; if not, they may not exceed $50 \%$ or five years. These restrictions do not apply to insured mortgages or to renewals of old loans, but total real estate loans must not exced the combined capital and surplus of the bank or $60 \%$ of its time and savings deposits, whichcver is greater.

11 Approximately $25 \%$ of all mortgages insured had been transferred by the end of June, I938. 
National Mortgage Associations. Provision for these associations was made by Title III of the National Housing Act. The Administrator was authorized to charter an association upon application of five or more natural persons who had paid on the capital stock of the association at least $\$ 5,000,000$ in cash or government securities. An association so chartered was given power to purchase and sell first mortgages up to $80 \%$ of the appraised value of the property on the date of purchasc and to issue notes, bonds, debentures, or other obligations up to ten times the par value of its outstanding capital stock, but not exceeding the face value of insured mortgages held by it plus its cash and government obligations. The associations themselves and their income, loans, stock, and securities were made subject to the same taxation as would apply to state-chartered corporations engaged in similar business. The Administrator was empowered to examine and supervise associations chartered by him.

No associations were organized under these provisions, and in an effort to attract capital to the field the Act of May 28, 1935, reduced the required capital to $\$ 2,000,000$ and increased the amount of obligations that might be outstanding to twelve times the par value of outstanding capital stock. This portion of the law still remained unused, however, and by the Act of February 3, 1938, it was further liberalized. Associations may now commence business with only one-fourth of their minimum capital paid in, and this payment may be made in mortgages of the types eligible, as well as in cash or government securities. No obligations may be issued, however, until the minimum capital is fully paid in one of these ways. Associations are now authorized to originate loans which are accepted for insurance or insured under Title II, ${ }^{112}$ as well as to purchase, service, or sell any mortgages thus insured, and they may also purchase, service, or sell uninsured first mortgages and other liens ${ }^{113}$ up to $60 \%$ of the value of the property. Their outstanding obligations may equal twenty times their paid-in capital and surplus, but must not exceed the unpaid principal of insured mortgages held plus cash and the amortized value of government obligations owned. The associations are made completely exempt from all federal, state, and local taxation, and their obligations are exempt from all such taxation except surtaxes, estate, inheritance, and gift taxes.

Since these amendments, considerable interest has been manifested by private capital, but the FHA has not issued regulations governing the organization and operation of private associations. On February 10, 1938, the Federal National Mortgage Association ${ }^{114}$ was chartered with a capital of $\$ 10,000,000$ and a paid-in surplus of $\$ 1,000,000$ furnished by the RFC. ${ }^{115}$ This association is now purchasing mortgages insured since January $\mathrm{I}$, 1937, covering properties on which improvements were begun since January I, I936, and is ready to make insured loans on large-scale

120 But no association controlled or operated by the United States or any of its agencies may originate loans accepted or insured under $\$ 203$, which confines lending by such an association to large scale rental projects.

${ }^{213}$ Until the 1938 amendments, other first liens.

13s The original name was "The National Mortgage Association of Washington."

${ }^{15}$ The RFC has stated that it is ready to contribute an additional $\$ 40,000,000$ to the capital of this and other national mortgage associations. Authority for such investments was containce in $\$ 5$ of the Act of Jan. 3 I, 1935 . 
rental projects. Mortgages are purchased without recourse, but only from approved mortgagees, who retain the servicing of the loans and as compensation receive an amount ranging from $1 / 2 \%$ to $1 \%$ of the unpaid principal. ${ }^{116}$ Thus the association obtains a yield of from $4 \frac{1}{4} \%$ to $4 \frac{1}{2} \%$ on the mortgages it purchases. It has recentily marketed an issue of $\$ 29,748,000$ of 5 -year, $2 \%$ notes, which was oversubscribed more than fifty times. At the end of June, 1938; the association had purchased mortgages totaling $\$ 41,948,122$, and had issued commitments to purchase an additional amount of $\$ 9,826,670$.

The RFC Mortgage Company. On March I4, I935, soon after passage of the law authorizing such investments, ${ }^{117}$ this company was organized with a capital of $\$ 10,000,000$ subscribed by the RFC. Additional funds are obtained by borrowing from the RFC. ${ }^{118}$ The original intention was to provide refinancing and new loans where private capital was not available in connection with business and other incomeproducing urban property, such as apartment houses. In 1936 the company began. purchasing from original mortgagees insured mortgages on newly constructed residences, but in 1937 it restricted such purchases to mortgages on property occupied in whole or in part by the mortgagor. Since organization of the national mortgage association, the company has ceased purchasing mortgages eligible for purchase by the association but has removed its other restrictions and now offers to buy without recourse at par and accrued interest all other insured mortgages. ${ }^{119}$ Thus the holder of any mortgage insured under Title II on which principal and interest payments are current may now sell it to one of these agencies. Arrangements for servicing mortgages purchased by the RFC Mortgage Company are similar to those of the national mortgage association. It should be noted, however, that these two agencies may cease purchasing mortgages at any time.

As of June $30,193^{8}$, the company had authorized the purchase of 19,333 mortgages totaling $\$ 84,586$, OI I and had actually purchased 14,903 mortgages amounting to $\$ 6 \mathrm{r}, 624,699$. Repayments and other reductions totaled $\$ 50,833,298$, of which $\$ 16,689$; 337 represented mortgages sold to the Federal National Mortgage Association. The company's total outstanding credit, including direct loans in addition to the mortgages purchased, was $\$ 40,674,886$.

Borrowing Facilities. For institutions which do not wish to dispose of their mortgages outright, provision has been made for their use as security for loans. The Home Loan Banks are authorized to lend to both members and non-members on the security of insured mortgages. ${ }^{120}$ The RFC also accepts mortgages as collateral for

\footnotetext{
${ }^{230}$ For the detailed regulations governing operations of the association, see its Circular No. I and Insured Mortgage Portfolio, May, 1938, p. 3.

${ }^{117}$ The Act of Jan. 31, 1935, which authorized the RFC to purchase stock in national mortgage associations or mortgage companies, with a maximum limit of $100,000,000$ on such purchases.

${ }^{113}$ At the end of June, I938, the RFC had increased its stock ownership to $\$ 25,000,000$ and had disbursed to the company a total of $\$ 79,171,157$.

${ }^{20}$ For a brief statement of the present arrangements, see Insured Mortgage Portrolio, June, 1938, p. 2. unused.

${ }^{200}$ As previously stated, however, the authorization for loans to non-members has been practically
} 
loans to financial institutions. The National Housing Act contained an amendment to the Federal Reserve Act making notes representing loans for the construction of residential or farm buildings with maturities of not more than six months eligible for rediscount at Federal Reserve Banks as commercial paper. The Federal Reserve Banks are also authorized by the Banking Act of 1935 , under rules and regulations prescribed by the Board of Governors, to make advances with maturities of not more than four months to members on their notes secured to the satisfaction of the Federal Reserve Bank, but such advances must bear interest at a rate at least $1 / 2 \%$ higher than the highest discount rate in effect at the Federal Reserve Bank making the advance. ${ }^{121}$ Regulation A, issued by the Board of Governors in September, 1937, lists nine types of security which will be considered as eligible collateral for such advances, and among these are included loans insured under Title I or Title II of the National Housing Act and uninsured mortgages meeting the legal requirements for national banks. ${ }^{122}$

\section{CONCLUSION}

In order to bring out the relationship between the various agencies described herein, it may be well to summarize the possible combinations of services which home financing institutions may obtain. State-chartered building and loan associations, whether or not they are members of the bank system, may obtain insurance of accounts. They may obtain membership in the bank system without insurance of accounts. An institution which secures either membership in the bank system or insurance of accounts may obtain share investments from the HOLC. ${ }^{123}$ Any member of the bank system may convert into a federal savings and loan association in accordance with the law of the state in which it is chartered, and new federal associations may be organized. All federal associations must be members of the bank system, must have their accounts insured, and may obtain share investments from the HOLC. ${ }^{124}$ Any financial institution approved by the FHA may have its mortgages insured.

Although provision for both was included in the same law, it is apparent from the preceding discussion that the insurance of mortgages has no connection with the insurance of accounts in building and loan associations. It should be noted, however, that the two insurance plans are not as different as is sometimes supposed. Both were put into effect as a means of attracting private capital to investment in urban home mortgages. Both operate on essentially the same principle, for when the Insur-

\footnotetext{
Im Previous emergency legislation, which expired in March, 1935, had authorized such advances in "exceptional and exigent circumstances" when the member bank could not furnish eligible collateral.

${ }^{18}$ Stated note i ro, supra.

20 But see the last sentence in the section dealing with this topic, p. 494, stipra.

${ }^{22}$ This relationship is slightly different from that which prevails in the commercial banking field, where all members of the Federal Reserve system must have their deposits insured. A similar requirement will be the logical future extension in the building and loan field, but the imposition of this requirement in the beginning would have greatly hindered the growth of the bank system. It has proved impossible so far to apply the converse of this in the commercial banking field by requiring that banks become mem. bers of the Federal Reserve system in order to have their deposits insured, but perhaps such a requirement may be anticipated as a development of the more distant future in both fields.
} 
ance Corporation guarantees repayment of funds placed by shareholders in lending institutions, it in reality guarantees the safety of the mortgages in which the institution in turn invests these funds. Moreover, if such a guarantee is to be provided, the insurance of mortgages directly, which is generally regarded as more "socialistic," "radical," and "unsound," is in some respects the safer and more desirable method, for in this case the insuring agency has an opportunity to pass in advance on the mortgages which it guarantees.

Through the agencies under jurisdiction of the Federal Home Loan Bank Board, the government has authorized the expenditure of funds and the pledging of its credit to the extent of $\$ 5,176,100,000^{125}$ Of this amount, $\$ 3,780,002,307$ had been utilized at the end of June, 1938. The funds advanced do not represent a subsidy, however, for all of them, with the exception of the small expense items, are supposed to be repaid and are supposed to earn interest and dividends. The extent of the subsidy cannot be measured until at some distant future date the amount of the expenditures and bond interest paid can be compared with the amount of the reimbursement and the interest and dividends received.

${ }^{225}$ The other agencies described herein are not included because their authorizations are less definite. In the case of the FHA, it is still uncertain whether the mutual mortgage insurance premiums will build up a fund sufficient to cover all insured mortgage losses. 